\title{
THE GENUS WORONICHINIA (CYANOBACTERIA) IN NATURAL LAKES OF DRAWA NATIONAL PARK (POLAND)
}

\author{
Paulina B. Nowicka-KrawczyK \& Joanna ŻelaZna-WieczoreK
}

\begin{abstract}
Woronichinia Elenkin is a cyanobacteria genus characteristic of lentic ecosystems. The type species, W. naegeliana (Unger) Elenkin, often blooms in the plankton of eutrophic reservoirs but this genus also contains species sensitive to high nutrient concentrations. The study analyzed the diversity and biomass of Woronichinia in lakes in a national park, isolated from the direct impact of human activity. The lakes were in various trophic states resulting from gradual and natural changes of trophy. Trophy was assessed with the use of the trophic diatom index, according to the classification we proposed for natural lakes. The relationship between the biomass and the trophic state of lakes was investigated with the use of multivariate unconstrained analysis with supplementary variables. Five species of Woronichinia were identified in all trophic types of lakes except for two oligotrophic ones: W. compacta (Lemmerm.) Komárek \& Hindák, W. delicatula (Skuja) Komárek \& Hindák, W. karelica Komárek \& Komárk.-Legn., W. obtusa Joosten and W. naegeliana (Unger) Elenkin. The occurrence and biomass of the species were related to the trophic state of the lakes. The absence of Woronichinia in two oligotrophic lakes could be due to the high concentration of humic compounds in the sediments. The low nitrogen-to-phosphorus ratio characteristic of the oligo-mesotrophic lakes resulted in increased species diversity. The lakes' isolation from human activity fostered the development of rare and sensitive species such as W. delicatula and W. karelica.
\end{abstract}

Key words: Cyanobacteria, diversity, natural eutrophication, trophic status, natural lakes, Woronichinia

Paulina B. Nowicka-Krawczyk \& Joanna Żelazna-Wieczorek, Laboratory of Algology and Mycology, Faculty of Biology and Environmental Protection, University of Łódź, Banacha 12/16, 90-237 Poland; e-mail: paulina.nowicka@biol.uni.lodz.pl; joanna. zelazna@biol.uni.lodz.pl

\section{INTRODUCTION}

In times of expanding urbanization and industrialization, aquatic ecosystems unaffected or slightly affected by human impacts are extremely rare. Changes in nutrient levels in these ecosystems are gradual, and transformation of environmental conditions from oligotrophy to eutrophy is very slow (Kociolek \& Stoermer 2009; Leng 2009). The diversity of cyanobacteria in naturally eutrophic ecosystems has been neglected by taxonomists, whose attention has been focused on cyanobacteria in anthropogenically changed ecosystems. Habitats that have maintained their natural character are important biodiversity sites due to their potential to host rare, sensitive, endangered and endemic species (Cantonati et al. 2012). Rising awareness of the threats to such ecosystems or habitats has led to their being placed under different forms of conservation (Kociolek \& Stoermer 2009; Cantonati et al. 2012).
The genus Woronichinia, distinguished and described by Elenkin (1933), is a characteristic genus of cyanobacteria in standing-water ecosystems. The type species of the genus, Woronichinia naegeliana (Unger) Elenkin, previously known as Coelospharium naegelianum Unger, is widespread in ecosystems with high nutrient content. It often blooms in the plankton of meso-eutrophic to eutrophic reservoirs, and produces toxins (Scot 1991; Skulberg et al. 1994; Wilk-Woźniak \& Mazurkiewicz-Boroń 2003; Wilk-Woźniak et al. 2006). Many Woronichinia species prefer oligo- and mesotrophic waters with low nutrient levels: for example, W. ruzickae Komárek \& Hindák or W. elorantae Komárek \& Komárk.-Legn. (Komárek \& Hindák 1988; Komárek \& Komárková-Legnerová 1992; Komárek \& Anagnostidis 2008).

Woronichinia is one of six genera of the Coelosphaeriaceae family (Komárek et al. 2014). 
Seventeen species were described within Woronichinia (Komárek \& Anagnostidis 2008; Joosten 2006; Komárek \& Hauer 2013). Two, Gomphosphaeria wichurae (Hilse \& Rabenhorst) Drouet $\&$ Daily and $W$. hungarica Hortobágyi, have an unclear status; probably they are morphotypes of W. naegeliana (Komárek \& Anagnostidis 2008). For the genera, Joosten (2006) distinguishes three species that are new combinations from the genus Coelomoron: W. pusilla (A. C. J. van Goor) Joosten, W. tropicalis (Senna, Peres \& Komárek) Joosten and W. microcystoides (Komárek) Joosten.

All Woronichinia species are limnophilic. The characteristic morphological structure of colonies allows Woronichinia to develop in habitats of lentic water ecosystems, such as the benthos, periphyton, metaphyton and plankton. New colonies develop from single cells released from old and disintegrated colonies in the form of expulsing cells. Longitudinal division of cells, perpendicular to one another in successive generations, and perpendicular to the colony surface, results in the formation of new colonies whose cells are arranged only at the peripheral layer. The cells are attached to a system of mucilaginous stalks, and the colonies are enveloped by hydrated mucilage often visible only after staining (Komárek \& Hindák 1988; Komárek \& Komárková-Legnerová 1992; Komárek \& Anagnostidis 2008; Pliński \& Komárek 2007). Such a structure of a colony allows it to float freely in the water column.

The genus Woronichinia is closely related phylogenetically to the genus Snowella Elenkin (Rajaniemi-Wacklin et al. 2006). The resemblance is reflected in their high morphological similarity. The two genera occur in similar habitats and often co-occur in aquatic ecosystems, but there are some differences in colony structure as a result of differences in reproduction and colony growth. Longitudinal division of the usually oval Woronichinia cells initiates a split of the mucilaginous stalks along their entire length. Such division results in the formation of a colony whose cells are attached to radially orientated stalks. The cells are arranged more or less densely on the colony surface, though relatively evenly, along the peripheral layer. The mucilaginous stalks are wide, often as wide as the width of the cells, and transparent, visible only after staining. In contrast to Woronichinia, Snowella has mostly spherical cells, also attached to mucilaginous stalks, but after cell division the stalks do not split along their entire length. As a result, a system of thin, branched and usually visible stalks is formed. The partial split of the stalks causes the difference in the arrangement of the cells at the colony surface. Snowella cells are arranged unevenly, sometimes irregularly, and within different layers at the periphery of the colony (Komárek \& Hindák 1988; Komárek \& Komárková-Legnerová 1992; Komárek \& Anagnostidis 2008).

This research addressed the diversity of the cyanobacteria genus Woronichinia in lakes characterized by various trophic states resulting from gradual and natural changes in trophy. The scope of the research included trophic status assessments of the lakes, taxonomic analyses of Woronichinia species, quantitative estimation of species based on their biomass, and analyses of the relationship between species occurrence (biomass) and environmental conditions (water $\mathrm{pH}$, conductivity, oxygen content, trophic state).

\section{STUDY AREA}

The research was conducted in 12 lakes in Drawa National Park (DNP), Poland (Fig. 1). DNP was created in 1990 to protect the unique glacial landscape of the southern part of the Pomeranian Lake District. The lakes were formed during the last Pleistocene glaciation (Vistulian glaciation) (Kraska 1997; Pawlaczyk 1997). All the lakes are in the valley of the Płociczna River, except for Arkońskie Lake which is in the valley of Moczel Stream. The lakes are surrounded by a hard-toreach forest area, and they differ due to the differences in the basins' morphometry, hydrology and land uses (Table 1).

The legal regulations stemming from conservation of the national park, and the lack of industry in the vicinity of the DNP, create an environment in which the lakes are isolated from direct human impacts. These aquatic ecosystems have not yet been transformed by humans and have maintained their 


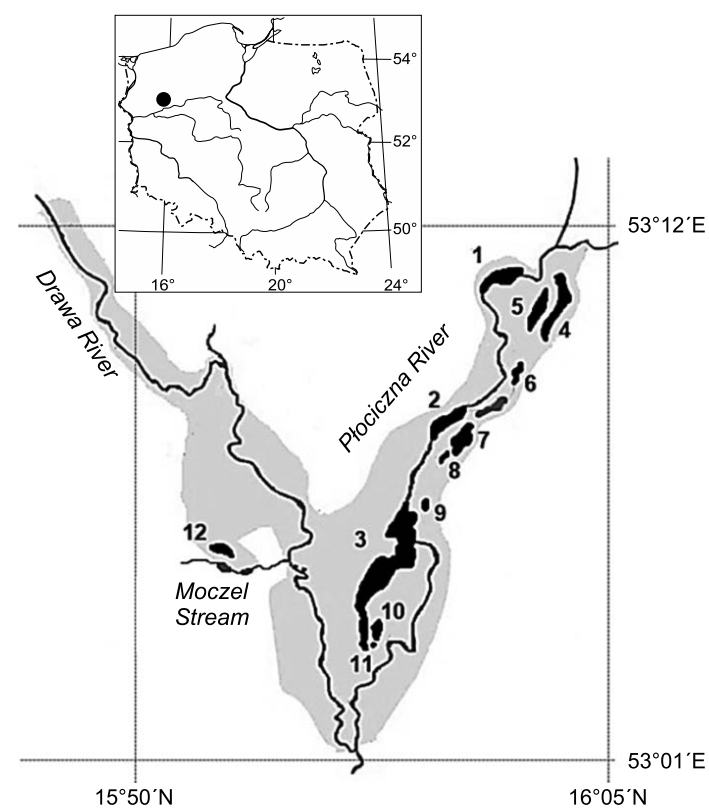

Fig. 1. Location of the studied lakes in Drawa National Park. 1 - Sitno, 2 - Płociczno, 3 - Ostrowieckie, 4 - Marta, 5 Płociowe, 6 - Zdroje, 7 - Piaseczno Duże, 8 - Piaseczno Małe, 9 - Pustelnik, 10 - Czarne, 11 - Perkoz, 12 - Arkońske.

natural character. The annual inflow of biogenic compounds to these outflow-type and non-outflow-type lakes is low and moderate. The average nitrogen-to-phosphorus ratio $(\mathrm{N}: \mathrm{P})$ ranges between $30: 1$ and $35: 1$. The main source of nutrients is surface runoff from the forest area and precipitation. Higher biogenic loads are noted in lakes on the course of the Płociczna River. There the N:P ratio is $c a 10: 1$, and these lakes are characterized by a higher trophic state (Szyper \& Kraska 1997, unpubl.).

\section{MATERIAL AND METHODS}

\section{ASSESSMENT OF THE ENVIRONMENTAL BACKGROUND}

Basic physical and chemical properties of water such as $\mathrm{pH}$, conductivity and dissolved oxygen were measured in May, June, July and September of 2013 with Elmetron CC-104, CP-401 and CO-401 field equipment.

The trophic status of the DNP lakes was assessed on the basis of indicator benthic diatoms. Benthic water samples for qualitative and quantitative analysis of diatom assemblages were collected in May, June, July and September 2013. Diatoms were extracted from the samples according to the procedure of ŻelaznaWieczorek (2011), embedded in Naphrax ${ }^{\circledR}$ resin, and analyzed on the basis of cell wall morphology. The quantitative shares of diatoms were estimated from each permanent slide by counting 400 diatom valves (Cholnoky 1968). The trophic diatom index (TDI) was calculated with the use of OMNIDIA 4.1 software, based on the qualitative and quantitative analyses. The trophic status of the ecosystems was classified according to the TDI value and the trophic classification following

Table 1. Characteristics of the studied lakes in Drawa National Park, according to Czerniawski et al. (2010) and Szyper and Kraska (1999, unpublished).

\begin{tabular}{|c|c|c|c|c|c|c|c|c|}
\hline \multirow[t]{2}{*}{ No. } & \multirow[t]{2}{*}{ Lake } & \multirow[t]{2}{*}{ Type } & \multirow[t]{2}{*}{ Area [ha] } & \multirow{2}{*}{$\begin{array}{c}\text { Mean / max. } \\
\text { depth }[\mathrm{m}]\end{array}$} & \multirow{2}{*}{$\begin{array}{c}\text { Capacity } \\
{\left[\mathrm{km}^{3}\right]}\end{array}$} & \multicolumn{2}{|c|}{$\begin{array}{c}\text { Nutrient input } \\
{[\mathrm{kg} / \text { year }]}\end{array}$} & \multirow{2}{*}{$\begin{array}{c}\text { Main source of } \\
\text { nutrients }\end{array}$} \\
\hline & & & & & & $\mathrm{N}$ & $\mathrm{P}$ & \\
\hline 1 & Sitno & on flow & 74.2 & $4.0 / 7.0$ & 2666.7 & 87608 & 8975 & Płociczna River \\
\hline 2 & Płociczno & on flow & 56.2 & $2.7 / 5.3$ & 1530.9 & 103267 & 9483 & Płociczna River \\
\hline 3 & Ostrowieckie & on flow & 387.6 & $9.4 / 28.5$ & 36433.1 & 111736 & 6657 & Płociczna river \\
\hline 4 & Marta & no outflow & 66.1 & $7.7 / 25.0$ & 5111.4 & 9949 & 318 & Forest \\
\hline 5 & Płociowe & no outflow & 35.3 & $10.3 / 25.0$ & 3620.0 & 2467 & 74 & Forest, precipitation \\
\hline 6 & Zdroje & outflow & 21.3 & $2.9 / 4.8$ & 612.1 & 3287 & 105 & Forest \\
\hline 7 & Piaseczno Duże & no outflow & 58.7 & $7.6 / 25.9$ & 4519.2 & 3030 & 87 & Forest, precipitation \\
\hline 8 & Piaseczno Małe & no outflow & 8.0 & $3.2 / 6.8$ & 258.4 & 418 & 12 & Forest, precipitation \\
\hline 9 & Pustelnik & outflow & 2.7 & $2.4 / 5.1$ & 65.76 & 686 & 22 & Forest \\
\hline 10 & Czarne & no ouflow & 19.1 & $11.5 / 29.0$ & 2196.5 & 846 & 24 & Forest, precipitation \\
\hline 11 & Perkoz & no ouflow & 1.3 & 2.07 / 4.6 & 27.7 & 68 & 2 & Forest, precipitation \\
\hline 12 & Arkońskie & ouflow & 13.1 & $2.7 / 3.8$ & n.d. & n.d. & n.d. & Forest, precipitation \\
\hline
\end{tabular}


Table 2. Physical and chemical properties of water, TDI values and trophic state of lakes in Drawa National Park.

\begin{tabular}{rlccccl}
\hline No. & \multicolumn{1}{c}{ Lake } & $\begin{array}{c}\text { Water } \\
\mathrm{pH}\end{array}$ & $\begin{array}{c}\text { Conductivity } \\
(\mathrm{mean})[\mu \mathrm{S} / \mathrm{cm}]\end{array}$ & $\begin{array}{c}\text { Oxygen } \\
\text { content } \\
(\mathrm{mean})[\mathrm{mg} / \mathrm{l}]\end{array}$ & $\begin{array}{c}\text { TDI } \\
(\mathrm{mean})\end{array}$ & Trophic state \\
\hline 1 & Sitno & 7.6 & 327 & 5.7 & 47.9 & Oligo-highly mesotrophic \\
2 & Płociczno & 7.8 & 312 & 8.1 & 67.7 & Eutrophic \\
3 & Ostrowieckie & 8.2 & 328 & 7.4 & 65.1 & Eutrophic \\
4 & Marta & 7.8 & 220 & 7.9 & 42.5 & Oligo-mesotrophic \\
5 & Płociowe & 8.1 & 236 & 8.2 & 40.1 & Oligo-mesotrophic \\
6 & Zdroje & 7.8 & 270 & 7.6 & 48.6 & Oligo-highly mesotrophic \\
7 & Piaseczno Duże & 8.3 & 303 & 8.1 & 37.1 & Oligo-slightly mesotrophic \\
8 & Piaseczno Małe & 7.9 & 85 & 6.6 & 33.8 & Oligotrophic \\
9 & Pustelnik & 7.6 & 39 & 5.3 & 31.7 & Oligotrophic \\
10 & Czarne & 8.3 & 271 & 7.4 & 39.4 & Oligo-slightly mesotrophic \\
11 & Perkoz & 8.1 & 331 & 6.4 & 35.2 & Oligo-slightly mesotrophic \\
12 & Arkońskie & 7.8 & 102 & 7.8 & 33.9 & Oligotrophic \\
\hline
\end{tabular}

Żelazowski et al. (2004). For the purpose of this research we proposed a division of the oligo-mesotrophic class according to Żelazowski et al. (2004) into three classes: oligo-slightly mesotrophic, oligo-mesotrophic, and oligo-highly mesotrophic, as follows: oligotrophy (TDI $\leq 35)$, oligo-slight mesotrophy $(35<\mathrm{TDI} \leq 40)$, oligo-mesotrophy $(40<\mathrm{TDI} \leq 45)$, oligo-high mesotrophy $(45<\mathrm{TDI} \leq 50)$, mesotrophy $(50<\mathrm{TDI} \leq 60)$, eutrophy $(60<\mathrm{TDI} \leq 75)$ and hypereutrophy (TDI $>75)$.

\section{CYANOBACTERIA ANALYSIS}

Benthic and metaphytic samples for cyanobacteria analysis were collected in May, June, July and September of 2013. Samples were collected live with a pipette aspirator into $125 \mathrm{ml}$ containers and maintained at $4{ }^{\circ} \mathrm{C}$ during transport to the laboratory. Then every sample was preserved with $2 \%$ solution of formaldehyde. Qualitative analysis was based on cell and colony morphology following Komárek and Hindák (1988), Komárek and Komárková-Legnerová (1992), Komárek and Anagnostidis (2008), Joosten (2006) and RajaniemiWacklin et al. (2006). Species diversity was studied by LM at $400 \times$ and $1000 \times$. Observations were documented with photographs taken with a Nikon E540 camera and scaled with Corel Photo-Paint X7 software at $1000 \times 1$ and $750 \times 1$.

The diameter of the Woronichinia colonies was measured ( $n=20$ for each species), and the average volume of the colonies was estimated from their diameter. Colonies were counted in a $0.05 \mathrm{ml}$ volume of precisely mixed, non-concentrated material for each sample. The average volume of the colonies $\left(\mathrm{Vc}_{\mathrm{i}}\left[\mathrm{mm}^{3}\right]\right)$ and the number of colonies $\left(\mathrm{Nc}_{\mathrm{i}}\right)$ was used for biomass estimation $\left(B_{i}\left[\mathrm{~mm}^{3} / \mathrm{ml}\right]\right)$ of each species in $1 \mathrm{ml}$ of sample, as follows:

$$
\mathrm{B}_{i}=\frac{\mathrm{V} c_{i} \times \mathrm{N} c_{i}}{0.05}
$$

The relationship between the biomass of the Woronichinia species and the basic properties of the water was assessed using multivariate constrained analysis - redundancy analysis (RDA). The trophic state of the lakes was determined using multivariate unconstrained analysis - principal component analysis (PCA) with supplementary variables. Both analyses employed CANOCO for Windows 5.1 (Lepš \& Šmilauer 2003).

\section{RESULTS}

\section{ENVIRONMENTAL BACKGROUND OF THE LAKES}

The water of the studied lakes was slightly alkaline. Water $\mathrm{pH}$ ranged from 7.6 in Pustelnik and Sitno Lake to 8.3 in Piaseczno Duże Lake and Czarne Lake. Conductivity ranged from $39 \mu \mathrm{S} / \mathrm{cm}$ in Pustelnik Lake to $331 \mu \mathrm{S} / \mathrm{cm}$ in Perkoz Lake. The lowest oxygen concentration $(5.3 \mathrm{mg} / \mathrm{l})$ was recorded in Pustelnik Lake, and the highest $(8.2 \mathrm{mg} / \mathrm{l})$ in Płociowe Lake.

The trophic diatom index ranged from 31.7 to 67.7. The highest TDI was noted in the lakes on the Płociczna River: Płociczno Lake and Ostrowieckie Lake. The lowest TDI was noted in two small 
lakes isolated from the Płociczna River (Piaseczno Małe Lake, Perkoz Lake) and in one larger lake in the Moczel stream valley (Arkońskie Lake). Following the trophic state classification proposed for the research, three lakes were oligotrophic, three oligo-slightly mesotrophic, two oligo-mestrophic, two oligo-highly mesotrophic and two eutrophic. Data on the chemical properties of the water and the trophic status of the studied lakes are compiled in Table 2.

\section{CYANOBACTERIA ANALYSIS}

Five Woronichinia species were noted in the lakes of Drawa National Park: W. karelica Komárek \& Komárk.-Legn. (Fig. 2A), W. delicatula (Skuja) Komárek \& Hindák (= Gomphosphaeria delicatula Skuja) (Fig. 2B), W. obtusa Joosten [=W. compacta auct., non $W$. compacta (Lemm.) Komárek

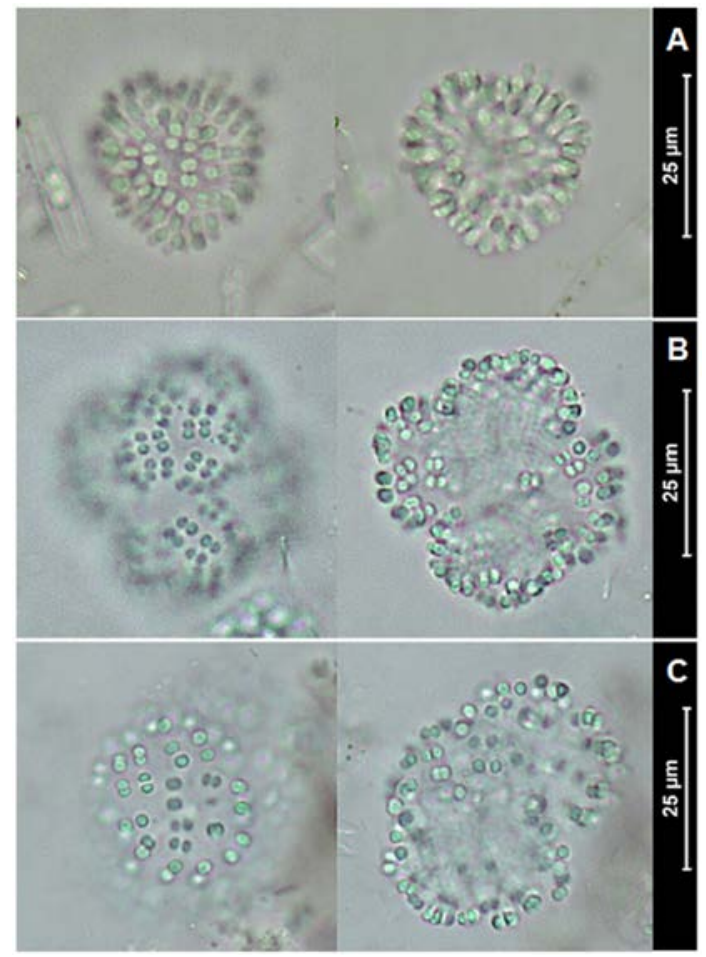

Fig. 2. Rare species of Woronichinia Elenkin identified in lakes of Drawa National Park. A - Woronichinia karelica Komárek \& Komárk.-Legn., B - Woronichinia delicatula (Skuja) Komárek \& Hindák, C - Woronichinia obtusa Joosten. Images present two planes of the colony.

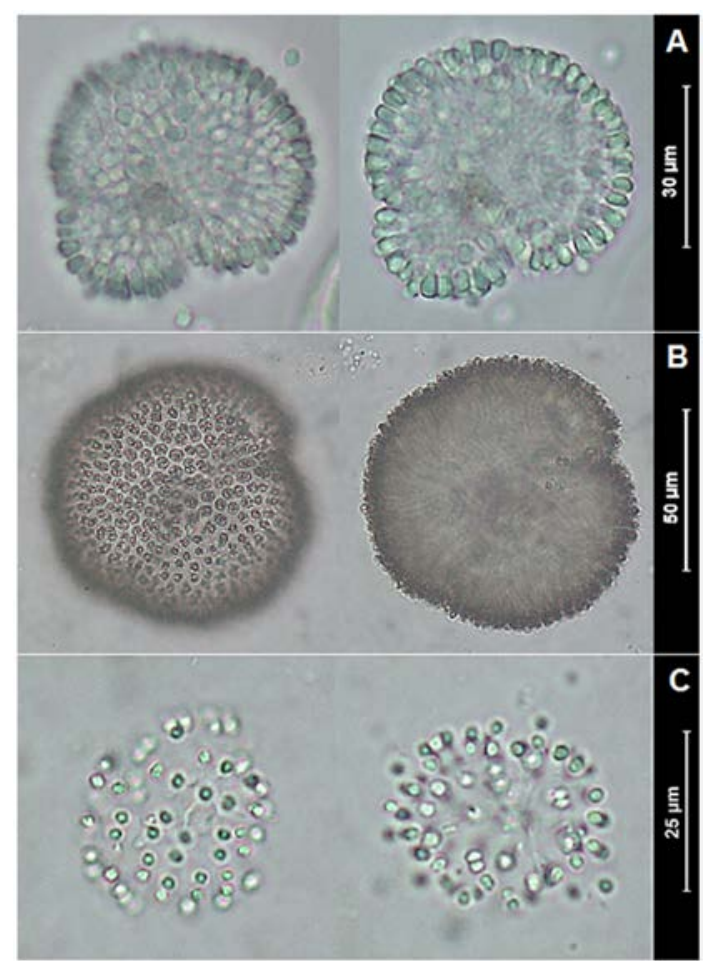

Fig. 3. Common species of Woronichinia Elenkin and Snowella Elenkin identified in lakes of Drawa National Park. A - Woronichinia compacta (Lemmerm.) Komárek \& Hindák. B - Woronichinia naegeliana (Unger) Elenkin. C - Snowella litoralis (Häyrén) Komárek \& Hindák. Images present two planes of the colony.

\& Hindák) (Fig. 2C), W. compacta (Lemmerm.) Komárek \& Hindák [= Gomphosphaeria lacustris var. compacta Lemm.; G. compacta (Lemm.) Ström] (Fig. 3A) and W. naegeliana (Unger) Elenkin [Coelosphaerium naegelianum Unger; Gomphosphaeria naegeliana (Unger) Lemm.] (Fig. 3B). The diagnostic characters of the identified species were in accordance with taxonomic references; data on the important morphological characters are compiled in Table 3. The morphologically similar species Snowella litoralis (Häyrén) Komárek \& Hindák (Fig. 3C) was present together with the Woronichinia species.

Species of Woronichinia were noted in all trophic types of lakes except for two oligotrophic ones: Piaseczno Małe Lake and Pustelnik Lake. Most of the species were present in the metaphyton. Only $W$. naegeliana was present exclusively in the 


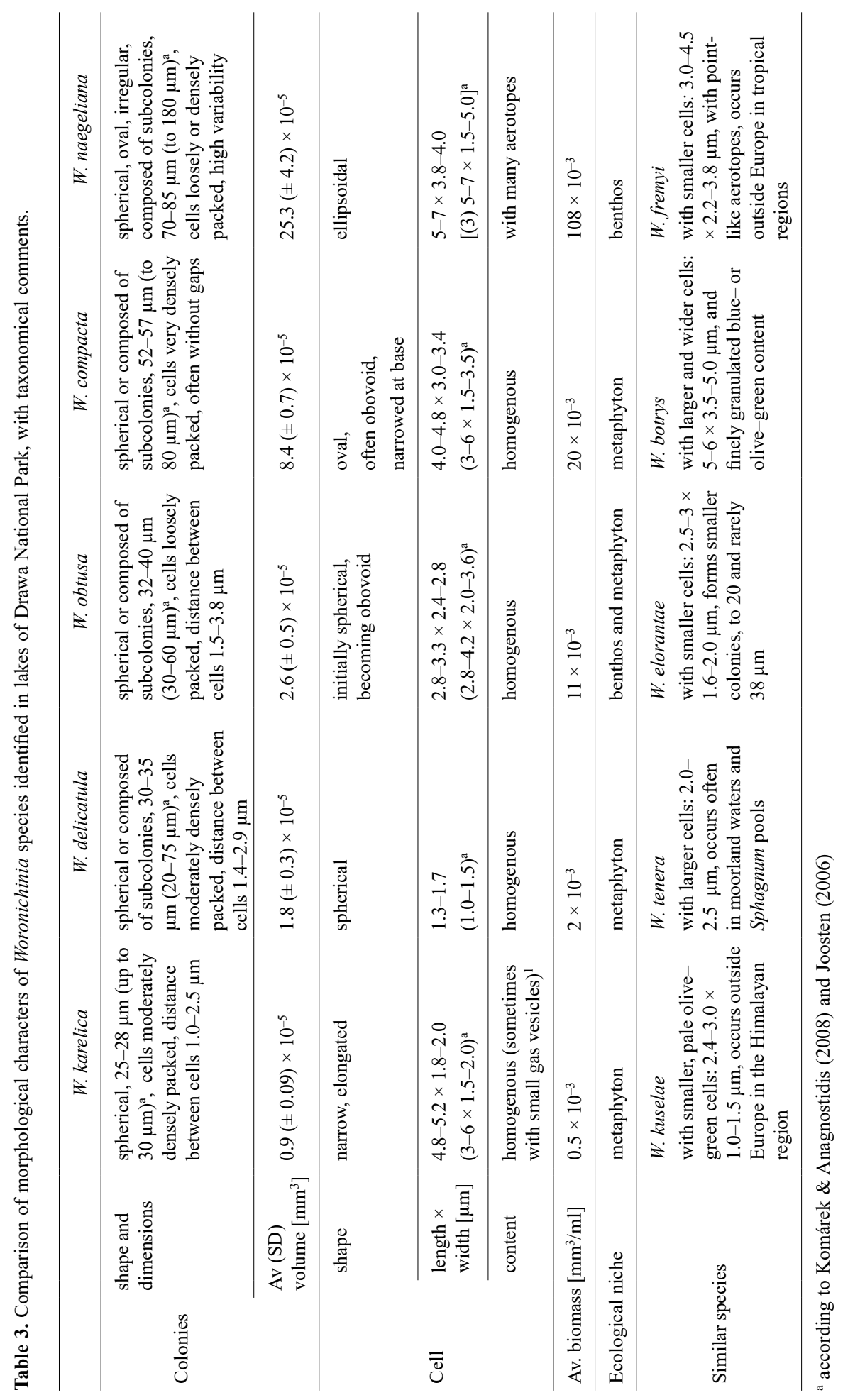


benthos. Together with Woronichinia, Snowella litoralis was present in all oligo-mesotrophic lakes (TDI: 35-50 according to Żelazowski et al.'s 2004 classification).

The average volumes of colonies for the Woronichinia species (measured for the purpose of determining species biomass) and the average biomass of species are compiled in Table 3. The biomass estimates of the Woronichinia species showed differences in the quantity of species between lakes of various trophic states. The least abundant species $\left(\mathrm{Nc}_{\mathrm{i}}=60 / \mathrm{ml}\right)$, with the lowest biomass $\left(\mathrm{B}_{\mathrm{i}}=0.5 \times 10^{-3} \pm 0.05 \times 10^{-3} \mathrm{~mm}^{3} / \mathrm{ml}\right)$, was $W$. karelica. It was recorded in only one, oligo-slightly mesotrophic Czarne Lake. Woronichinia compacta was also noted in oligo-slightly mesotrophic lakes but at slightly higher abundance and high biomass (Czarne Lake: $\mathrm{Nc}_{\mathrm{i}}=160 / \mathrm{ml}$; $\mathrm{B}_{\mathrm{i}}=13.4 \times 10^{-3} \pm 1.1 \times 10^{-3} \mathrm{~mm}^{3} / \mathrm{ml}$; Perkoz Lake: $\mathrm{Nc}_{\mathrm{i}}=80 / \mathrm{ml} ; \mathrm{B}_{\mathrm{i}}=6.7 \times 10^{-3} \pm 0.5 \times 10^{-3} \mathrm{~mm}^{3} / \mathrm{ml}$ ). Woronichinia delicatula was recorded in only one, oligo-mesotrophic Marta Lake. The abundance and biomass of this species were low $\left(\mathrm{Nc}_{\mathrm{i}}=120 / \mathrm{ml}\right.$; $\mathrm{B}_{\mathrm{i}}=2.2 \times 10^{-3} \pm 0.3 \times 10^{-3} \mathrm{~mm}^{3} / \mathrm{ml}$ ).

Woronichinia obtusa was the most common species and had the highest number of colonies. It was present in all trophic types of lakes with the exception of oligotrophic. The number of colonies increased along the trophic state gradient, reaching maximum in oligo-highly mesotrophic Zdroje Lake (in the benthos $\mathrm{Nc}_{\mathrm{i}}=200 / \mathrm{ml} ; \mathrm{B}_{\mathrm{i}}=5.2 \times 10^{-3} \pm 1.0$ $\times 10^{-3} \mathrm{~mm}^{3} / \mathrm{ml}$; in the metaphyton $\mathrm{Nc}_{\mathrm{i}}=320 / \mathrm{ml}$; $\mathrm{B}_{\mathrm{i}}=8.3 \times 10^{-3} \pm 1.7 \times 10^{-3} \mathrm{~mm}^{3} / \mathrm{ml}$ ).

Woronichinia naegeliana was present only in the benthos of two lakes with extreme trophic states (oligo- and eutrophic). It occurred with 560 colonies per $\mathrm{ml}$ and biomass $141.6 \times 10^{-3} \pm 23.8 \times$ $10^{-3} \mathrm{~mm}^{3} / \mathrm{ml}$ in oligotrophic Arkońskie Lake, while in eutrophic Płociczno Lake it occurred with 300 colonies per $\mathrm{ml}$ and biomass $75.9 \times 10^{-3} \pm 12.7 \times$ $10^{-3} \mathrm{~mm}^{3} / \mathrm{ml}$.

The standard deviation of the variables in the multivariate constrained analysis was 6.5 ; therefore RDA was used to summarize part of the variation of species composition explained by environmental variables. The adjusted explained variation was $44 \%$. The analysis showed that the
$\mathrm{pH}$, conductivity and TDI vectors were the most significant ones in arranging taxa in the ordination space. Woronichinia obtusa showed a positive correlation with conductivity and TDI, and $W$. compacta and W. karelica with $\mathrm{pH}$ (Fig. 4).

The standard deviation of variables in the multivariate unconstrained analysis was 0.6 ; therefore PCA with supplementary variables was used to summarize the variation of species composition and to interpret this summary with the help of environmental variables. The adjusted explained variation was $52.8 \%$, while the supplementary variables accounted for $59.6 \%$. Vertical axes divided the ordination plot due to trophic state into oligo- and close to oligotrophic, where environmental vectors had a high multiple correlation with the ordination axes; and into oligo-meso to eutrophic, where environmental vectors showed a low correlation with the ordination axes (Fig. 5). The PCA biplot revealed a relationship between the biomass of the Woronichinia species and the trophic state of the lakes. A strong positive relationship with oligotrophic state was recorded among $W$. delicatula and W. naegeliana, and with oligo-slightly mesotrophic

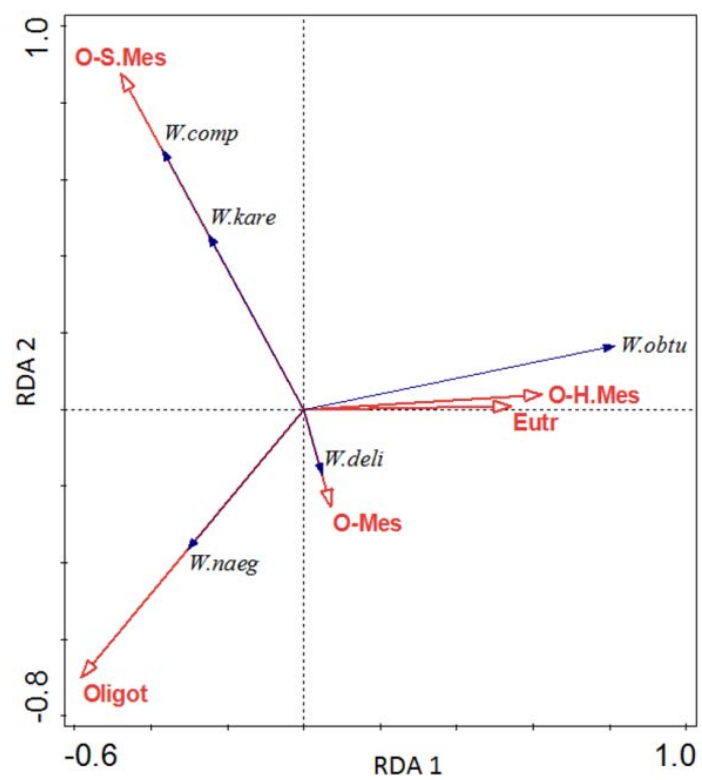

Fig. 4. RDA biplot of the relationship between Woronichinia species biomass and the basic properties of water in the lakes of Drawa National Park. 


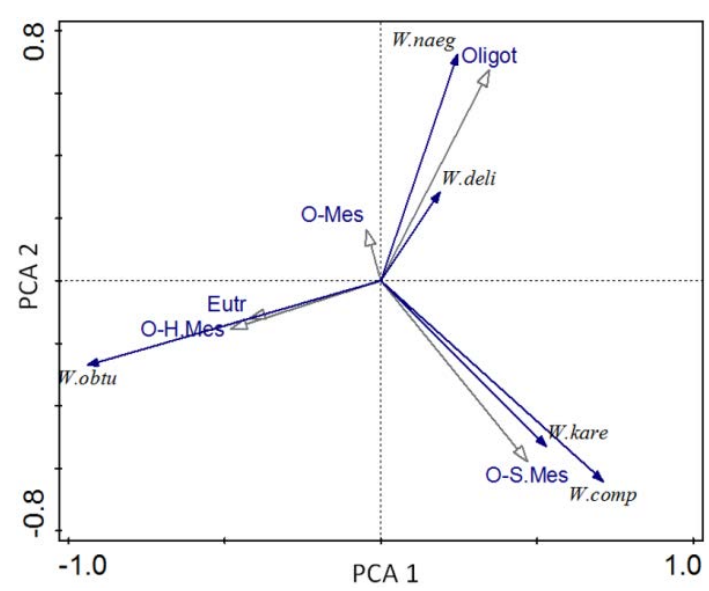

Fig. 5. PCA biplot of the relationship between Woronichinia species biomass and the trophic state of the studied lakes of Drawa National Park; oligotrophy (Oligot); oligo-slight mesotrophy (O-S Mes); oligo-mesotrophy (O-Mes); oligo-high mesotrophy (O-H Mes); eutrophy (Eutr).

state among $W$. karelica and $W$. compacta. The presence of $W$. obtusa was highly related to ecosystems with elevated nutrient content.

\section{Discussion}

We found the genus Woronichinia to be taxonomically diverse in natural lakes of Drawa National Park (DNP). The lakes are isolated from direct human impacts, which reduces the rate of their natural eutrophication. The factors that cause changes of trophy in natural ecosystems are associated mainly with basin morphology, biological processes in the ecosystem (e.g., mineralization rate) and external sources of nutrients (Leng 2009). All lakes in DNP were formed during the Vistulian glaciation but they are at different stages of natural eutrophication, as confirmed by diatom bio-assays using the trophic diatom index (TDI). The trophy of lakes isolated from the river course is elevated mainly by nutrient inflow from the forest area and from precipitation. Depending on basin morphology and the intensity of biological processes in the ecosystem, lakes are more or less susceptible to acceleration of eutrophication. In shallow lakes like Zdroje Lake, mixing of water results in the release of nutrients from sediments and increasing eutrophication, but if the bottom of the lake is covered with vegetation, as in Arkońskie Lake, the vegetation binds the sediments and prevents it from releasing nutrients into the water. Lakes located on the river course are supplied with nutrients mainly through river inflow. The share of this source of nutrients may even reach $94 \%$, as in Sitno Lake (Czerniawski \& Piasecki 2004; Szyper \& Kraska 1999, unpubl.; Kraska 1998, unpubl.; Kraska \& Piotrowicz 1998, unpubl.). Most of the lakes of DNP are oligo-mesotrophic. This trophic state promoted the diversity of the Woronichinia species, because many species of this genus prefer oligo-mesotrophic conditions. In eutrophic reservoirs, especially in those transformed by human activity, the diversity of Woronichinia is low, and such reservoirs generally include $W$. naegeliana and its morphotypes (Komárek \& KomárkováLegnerová 1992; Komárek \& Anagnostidis 2008; Pliński \& Komárek 2007). However, a study of the cyanobacteria microflora in the Netherlands (Joosten 2006) revealed Woronichinia diversity in eutrophic reservoirs. These reservoirs were classified as eutrophic but were characterized by low human impacts. They could in fact be closer to moderately eutrophic, because the species diversity of Woronichinia in such conditions is higher than in anthropogenically transformed reservoirs with a disturbed ratio of nitrogen to phosphorus (Santos et al. 2012).

The low $\mathrm{N}: \mathrm{P}$ ratio characteristic for the oligo-mesotrophic lakes isolated from the river in DNP resulted in increased Woronichinia species diversity. In general, the biomass and abundance of cyanobacteria are higher in ecosystems with a high $\mathrm{N}$ : $\mathrm{P}$ ratio than in those with a low $\mathrm{N}: \mathrm{P}$ ratio (Havens et al. 2003); in the case of the Woronichinia genus, which prefers waters with moderate fertility, a low ratio of these nutrients favors its species diversity.

The division of the oligo-mesotrophic class into three classes of increasing mesotrophic conditions allowed us to examine the relations between the occurrence of certain species and the trophic state of the lakes. The least abundant species were $W$. karelica and $W$. delicatula. Both species occur in oligotrophic and oligo-mesotrophic reservoirs of Europe (Komárek \& Anagnostidis 2008) but 
until now they had not been recorded in the water ecosystems of Poland. Pliński and Komárek (2007) mentioned the potential occurrence of $W$. karelica in the Baltic Bay, as it is present in the Eastern Baltic region (Hällfors 2004), but until now the presence of this species in Poland had not been noted. The results of our study in DNP confirm the ecological preferences of both species regarding trophy state, and suggest that the presence of $W$. karelica may be related to high water $\mathrm{pH}$.

The presence of $W$. compacta was noted in two ecosystems of oligo-slightly mesotrophic type with high water $\mathrm{pH}$. This species is commonly recorded in Poland in various trophic conditions, especially in the Baltic region (Pliński \& Komárek 2007). Its presence only in oligo-slightly mesotrophic lakes in DNP is puzzling, as it has a wide tolerance to trophy and from time to time is a dominant species in eutrophic ecosystems (Krevs et al. 2007).

Woronichinia obtusa, distinguished by Joosten (2006) from the $W$. compacta complex, was predominant, occurring in the highest numbers in DNP. This species preferred oligo-mesotrophic to eutrophic waters with high conductivity. Its biomass gradually increased with increasing trophy, reaching the highest biomass in oligo-highly mesotrophic conditions. In eutrophic waters, where the ratio of $\mathrm{N}: \mathrm{P}$ was higher, its biomass decreased. Joosten (2006) noted that in the cyanobacteria microflora of the Netherlands it is often present in eutrophic reservoirs. Our study in DNP showed different trophic state preferences. The reservoirs in the Netherlands may be closer to moderately eutrophic, as mentioned above. Moreover, the character of the water ecosystems in Joosten's (2006) studies and at the DNP differ due to latitude and geology; this might account for the divergence of findings. Until now this species had not been recorded in Poland, but it may have been identified as $W$. compacta or under the former name Gomphosphaeria compacta (Siemińska \& Wołowski 2003).

Woronichinia naegeliana was present both in eutrophic and in oligotrophic lakes of DNP. It occurred with higher biomass in the oligotrophic lake than in the eutrophic one. This may not be surprising, since Brettum (1989) classified this species as characteristic for oligo-mesotrophic waters; however, later studies revealed the presence of $W$. naegeliana in meso-eutrophic and eutrophic reservoirs (Wilk-Woźniak \& Mazurkiewicz-Boroń 2003; Wilk-Woźniak et al. 2006; Joosten 2006). This suggests that $W$. naegeliana may have a wide tolerance to trophy. Its wide occurrence and potentially wide tolerance to trophy may explain why this species has high morphological variability (Komárek \& Komárková-Legnerová 1992).

A study of cyanobacteria in 1997 by SzelągWasilewska and Gołdyn (1998, unpubl.) in DNP mentions only the presence of Gomphosphaeria species, which were transferred in 1988 to the genus Snowella by Komárek and Hindák (1988). The authors did not mention the presence of Woronichinia species in the lakes. They identified only Gomphosphaeria rosea (Snow) Lemmerm. G. rosea sensu Lemmermann (1907-1910) was transferred to Snowella (Elenkin 1938), but the typical Snowella rosea (Snow) Elenkin occurs only outside Europe, in waterbodies of North America (Smith 1920; Komárek \& Anagnostidis 2008). Most likely, G. rosea sensu Komárek (Komárek 1958) was recorded at the DNP. This species was transferred to Snowella in 1988 as Snowella litoralis (Komárek \& Hindák 1988). We recorded S. litoralis; it co-occurred with Woronichinia species in oligo-mesotrophic lakes. The ecological preferences of $S$. litoralis are in line with the references (Komárek \& Hindák 1988; Komárek \& Anagnostidis 2008).

Woronichinia species were absent in two oligotrophic lakes: Piaseczno Małe and Pustelnik. Both lakes had high concentrations of humic compounds in the sediment and low levels of dissolved oxygen during the study period. The low concentrations of nutrients and oxygen, and the lower water $\mathrm{pH}$ than in the other studied lakes, may together have created unfavorable conditions for the development and growth of Woronichinia species.

As compared with Joosten's (2006) findings, the taxonomical diversity of the genus Woronichinia in Drawa National Park can be considered high. Such diversity is a result of the nature of these ecosystems: natural, undisturbed by direct human impacts, and with different trophy resulting from natural processes of ecosystem 
transformation. Rare and sensitive species such as $W$. karelica and $W$. delicatula have developed in these ecosystems. The fact that these habitats are inside a national park, are protected from the direct effects of human activity and are isolated from anthropogenic processes of ecosystem transformation is very important. This isolation has permitted gradual, natural changes in the trophy of these lakes. In view of previous studies (SzelągWasilewska \& Gołdyn 1998, unpubl.), we infer that the conservation of these ecosystems has led to an increase in the species diversity of the studied genus. Protection of unique ecosystems is essential for maintaining species diversity.

ACKNOWLEDGEMENTS. We are grateful to the anonymous reviewers for helpful remarks and suggestions on the manuscript. This research was a part of a cyanobacterial diversity study for the Water Ecosystems Protection Authority of Drawa National Park, and was supported by University of Łódź Task Grants for young researchers (No. B1311000000100.02, No. B1411000000698.02).

\section{REFERENCES}

BRetTUM P. 1989. Algar som indicator på vannkvalitet i norske innsjøer. Planteplankton. NIVA Rapport 2344: 1-111.

Cantonati M., Füreder L., Grecke R., Jüttner I. \& Cox E. J. 2012. Crenic habitats, hotspots for freshwater biodiversity conservation: toward an understanding of their ecology. Freshwater Science 31: 463-480.

Cholnoky B. 1968. Die Ökologie der Diatomeen in Binnengewässern. J. Cramer Verlag, Stuttgart.

Czerniawski R. \& Piasecki W. 2004. Rozwój makrofitów w jeziorze Adamowo i rozlewisku rzeki Drawy jako efekt eutrofizacji. Komunikaty Rybackie 6: 7-10.

Czerniawski R., Pilecka-Rapacz M. \& Domagala J. 2010. Evaluation of the trophic status of the lakes localized in the Drawa River drainage in relation to environmental conditions of catchment. In: A. GrZeŚKOWIAK \& B. NowAK (eds), Dynamics of natural processes in the Drawa River catchment in the Drawa National Park, pp. 27-37.Wieland Drukarnia Cyfrowa, Poznań (in Polish with English summary).

Elenkin A. A. 1933. About new family of blue-green algae from Stereometreae Elenk. group (Excavatae Elenk. subgroup) order Chroococcales Geitler (1925). Trudy Botanicheskogo Instituta Akademii Nauk SSSR 2: 23-34.

Elenkin A. A. 1938. Sinezelenye vodorosli. Pars spec. (1-2) Izdatel'stvo AN SSSR, Moskva - Leningrad.
HÄLlfors G. 2004. Checklist of Baltic Sea Phytoplankton Species. Baltic Sea Environmental Proceedings, Helsinki Commission, Baltic Marine Environment Protection Commission 95: 1-208.

Havens K. E., James T. R., East T. L. \& Smith V. H. 2003. $\mathrm{N}: \mathrm{P}$ ratios, light limitation, and cyanobacterial dominance in a subtropical lake impacted by non-point source nutrient pollution. Environm. Pollut. 122: 379-390.

Joosten A. M. T. 2006. Flora of the blue-green algae of the Netherlands. I. The non-filamentous species of inland waters. KNNV Publishing, Utrecht.

Kociolek J. P. \& Stoermer E. F. 2009. Oligotrophy: the forgotten end of an ecological spectrum. Acta Bot. Croat. 68: $465-472$.

KomáreK J. 1958. Die taxonomische Revision der planktischen Blaualgen der Tschechoslowakei. In: J. KOMÁREK \& H. ETTL (eds), Algologische Studien. pp. 10-206. Verlag der Tschechoslowakischen Akademie der Wissenschaften, Praha.

KomáreK J. \& Anagnostidis K. 2008. Cyanoprokaryota I. Chroococcales. In: H. Ettr, G. Gärtner, H. Heynig \& D. Mollenhauer (eds), Süßwasserflora von Mitteleuropa. 19(1): 192-224. Spektrum Akademischer Verlag, Heidelberg.

KomÁReK J. \& Hauer T. 2013. CyanoDB.cz - On-line database of cyanobacterial genera. University of South Bohemia \& Institute of Botany, Academy of Sciences of the Czech Republic. [July 2014]. http://www.cyanodb.cz.

KomÁReK J. \& HindÁK F. 1988. Taxonomic review of natural populations of the cyanophytes from the Gomphosphaeriacomplex. Algol. Stud. 50-53: 203-225.

KomáreK J. \& KomÁrKová-Legnerová J. 1992. Variability of some planktic gomphosphaerioid cyanoprokaryotes in northern lakes. Nordic J. Bot. 12: 513-524.

KomáreK J., Kaštovský J., Mareš J. \& Johansen J. R. 2014. Taxonomic classification of cyanoprokaryotes (cyanobacterial genera) 2014, using a polyphasic approach. Preslia 86: $295-335$.

KRASKa M. 1997. Jeziora w Drawieńskim Parku Narodowym. Aura 8: 14-16.

Krevs A., Koreiviene J., Paskauskas R. \& Sulijiene R. 2007. Phytoplankton production and community respiration in different zones of the Curonian lagoon during the midsummer vegetation period. Transitional Waters Bulletin 1: 17-26.

Lemmermann E. 1907-1910. Algen I. In: E. Kummer (ed.), Kryptogammen Flora. 3. Mark, Brandenburg.

LENG R. 2009. The impacts of cultural eutrophication on lakes: A review of damages and nutrient control measures. Writing 20: 33-39.

LEPŠ J. \& ŠMILAUER P. 2003. Multivariate Analysis of Ecological Data using CANOCO. Cambridge University Press, Cambridge UK. 
PaWlaCzYK P. 1997. Gleby i roślinność ekosystemów leśnych w Drawieńskim Parku Narodowym. Sorus, Poznań.

Pliński M. \& KomÁReK J. 2007. Blue-green algae - Cyanobacteria (Cyanoprokaryota). In: M. PLIŃsKI (ed.), Flora Zatoki Gdańskiej $i$ wód przyległych (Bałtyk Południowy). 1: 1-172. Wydawnictwo Uniwersytetu Gdańskiego, Gdańsk.

Rajaniemi-Wacklin P., Rantala A., Mugnai M. A., Turicchia S., Ventura S., Komárková J., Lepistö L. \& Sivonen K. 2006. Correspondence between phylogeny and morphology of Snowella spp. and Woronichinia naegeliana, cyanobacteria commonly occurring in lakes. J. Phycol. 42: 226-232.

Santos M. C. R., Muelle H. \& Pacheco D. M. D. 2012. Cyanobacteria and microcystins in lake Furnas (S. Miguel Island - Azores). Limnetica 31: 107-118.

Scot W. E. 1991. Occurrence and significance of toxic cyanobacteria in Southern Africa. Wat Sci Tech. 23: 175-180.

Siemińska J. \& WoŁowski K. 2003. Catalogue of Polish prokaryotic and eukaryotic algae. W. Szafer Institute of Botany, Polish Academy of Science. Kraków.

Skulberg O. M., Underdal B. \& UtKilen H. 1994. Toxic waterblooms with cyanophytes in Norway - current knowledge. Algol. Stud. 75: 279-289.
Smith G. M. 1920. Phytoplankton of the Inland Lakes of Wisconsin. I. Bull. Wisconsin Geol. Nat. Hist. Surv. 57(12): $1-243$.

Wilk-Woźniak E. \& Mazurkiewicz-Boroń G. 2003. The autumn dominance of cyanoprokaryotes in a deep mesoeutrophic submarine reservoir. Biologia (Bratislava) 58(1): 17-24.

Wilk-Woźniak E., Cerbin S., Marshall H. G. \& BurCHARDT L. 2006. Ultra-structure of two common cyanobacteria: Microcystis aeruginosa Kutz. and Woronichinia naegeliana (Unger) Elenkin using scanning electron microsopy. Algol. Stud. 121: 85-89.

ŻELAZnA-WieczoreK J. 2011. Diatom flora in springs of Łódź Hills (Central Poland), Biodiversity, taxonomy, and temporal changes of epipsammic diatom assemblages in springs affected by human impact. In: A. WiTKOwsKi (ed.), Diatom Monographs. 13: 31-38. ARG. Gantner Verlag $\mathrm{KG}$, Ruggell.

Żelazowski E., Magiera M., Kawecka B., Kwadrans J. \& Kотоwicz J. 2004. Use of algae for monitoring rivers in Poland - in the light of a new law for environmental protection. Oceanological and Hydrobiological Studies 33: $27-39$. 